\title{
Mechanism of Laccase-assisted Tyrosine Grafting on Keratin using BSA as a Model Protein
}

\author{
$\mathrm{Yu} \mathrm{Li}{ }^{1}$, Jing $\mathrm{Su}^{1}$, Tarsila G. Castro ${ }^{2}$, and Artur Cavaco-Paulo ${ }^{3}$ \\ ${ }^{1}$ Jiangnan University \\ ${ }^{2}$ University of Minho \\ ${ }^{3}$ Univ. Minho
}

October 28, 2021

\begin{abstract}
Commercial hair perming uses strong reducing agents and is harmful to hair fiber's quality even human health. In this study, tyrosine is adopted as a cross-linking agent between thiols as the shape-changing of hair involves breakage of disulfide bonds and the rearrangement of new bonds between keratin molecules. To investigate the mechanism of the cross-linking, bovine serum albumin (BSA) is used as a model protein. Molecular dynamics simulations give an insight on Cys solvent accessibility and protein stability for the wild type BSA and a designed BSA presenting the three broken disulfide bonds. A new cross-linked peptide, NECFLSHK-Tyrosine-Tyrosine-GACLLPK, inter- or intra- BSA monomers is formed, whose reactive cysteine residues are Cys-101 and Cys-176. Moreover, curling of Asian hair is conducted using tyrosine as a perming agent by laccase-assisted reaction. The optimized operational conditions are hair with cysteine pre-treatment $(50.0 \mathrm{mM})$ followed by grafting with 3.0 $\mathrm{mM}$ tyrosine. The reshaped hair performed a better perming performance than commercial perming product before washing, although a lower perming efficiency after washing, however without strength loss and could be easily accomplished with a blow-drier. Hence, this new methodology may lead to the development of a gentle and user-friendly approach in the hair care industry.
\end{abstract}

\section{Hosted file}

Main_text.docx available at https://authorea.com/users/443445/articles/543418-mechanism-oflaccase-assisted-tyrosine-grafting-on-keratin-using-bsa-as-a-model-protein

\section{Hosted file}

Figures.docx available at https://authorea.com/users/443445/articles/543418-mechanism-oflaccase-assisted-tyrosine-grafting-on-keratin-using-bsa-as-a-model-protein 